\title{
Faktor-faktor yang mempengaruhi belanja pembangunan
}

\author{
Sajid Ikhsan Fuad ${ }^{1}$, Muhammad Saleh Mire ${ }^{2}$, Aji Sofyan Effendi ${ }^{3}$ \\ Magister Ilmu Ekonomi, Fakultas Ekonomi dan Bisnis Universitas Mulawarman, Samarinda. \\ ${ }^{1}$ Email: sajid.ikhsan.fuad@mhs.feb.unmul.ac.id \\ ${ }^{2}$ Email: muhammad.Saleh.mire@feb.unmul.ac.id \\ ${ }^{3}$ Email: aji.sofyan.effendi@feb.unmul.ac.id
}

\begin{abstract}
Abstrak
Belanja daerah menurut Kepmendagri Nomor 13 Tahun 2006. Pengeluaran daerah adalah uang yang keluar dari kas daerah dimana Kas Umum Daerah adalah tempat penyimpanan uang daerah yang ditentukan oleh kepala daerah untuk menampung seluruh penerimaan daerah dan digunakan untuk membayar seluruh pengeluaran daerah. Belanja langsung terdiri dari belanja pegawai, belanja modal dan belanja barang dan jasa. Penelitian ini bertujuan untuk (1) menganalisis besarnya pengaruh langsung Pendapatan Asli Daerah, Dana Alokasi Umum, Dana Bagi Hasil Pajak/Bagi Hasil Bukan Pajak dan Pertumbuhan Ekonomi terhadap Belanja Pembangunan di Provinsi Kalimantan Timur; (2) menganalisis antara Pendapatan Asli Daerah, Dana Alokasi Umum, Dana Bagi Hasil Pajak/Bagi Hasil Bukan Pajak dan Pertumbuhan terhadap Belanja Pembangunan (Belanja Modal dan Belanja Barang Jasa) di Provinsi Kalimantan Timur yang manakah yang lebih dominan. Data yang digunakan dalam penelitian ini adalah data sekunder yang diperoleh dari Badan Pusat Statistik dan Statistik Provinsi Kalimantan Timur, Dinas Pendapatan Daerah Provinsi Kalimantan Timur, Bappeda Provinsi Kalimantan Timur dan Biro Keuangan Setda Provinsi Kalimantan Timur pada tahun 2005 sampai dengan 2014. Dimana penelitian ini menggunakan alat analisis regresi linier berganda) yang dibantu dengan program SPSS17. Hasil analisis menunjukkan bahwa variabel pendapatan asli daerah berpengaruh signifikan sedangkan dana alokasi umum, dana bagi hasil pajak/bagi hasil bukan pajak, dan pertumbuhan ekonomi berpengaruh tidak signifikan terhadap belanja pembangunan. Kemudian variabel independen yang memiliki pengaruh dominan secara signifikan terhadap variabel dependen yaitu variabel pendapatan asli daerah.
\end{abstract}

Kata Kunci: Pendapatan Asli Daerah

\section{Factors affecting the development expenditure}

\begin{abstract}
This study aims to (1) analyze the magnitude of the direct influence PAD, General Allocation Fund, DBH Taxes / Profit Sharing Taxes and Economic Growth Not to Shopping Development in East Kalimantan Province; (2) analyze the PAD, General Allocation Fund, DBH Taxes / Profit Sharing Taxes and Growth Not to Development Expenditure (Capex and Expenditure Goods and Services) in the province of East Kalimantan which is more dominant. The data used in this research is secondary data obtained from the Central Bureau of Statistics and Statistics of East Kalimantan Province, the Department of Revenue Province of East Kalimantan, East Kalimantan provincial Bappeda and the Finance Bureau of East Kalimantan Provincial Secretariat in 2005 through 2014. Where this study using multiple linear regression analysis) assisted with SPSS17 program. The analysis showed that the variables significantly affect local revenues while the general allocation fund, tax sharing / of non-tax revenue and economic growth not significant effect on development expenditure. Then the independent variables that have a dominant influence significantly on the dependent variable is the variable revenue.
\end{abstract}

Keywords: Local Own Resources (PAD) 


\section{PENDAHULUAN}

Perkembangan daerah di Indonesia semakin pesat, seiring dengan adanya era baru dalam pelaksanaan otonomi daerah dan desentralisasi fiskal. Kebijakan otonomi daerah ditandai dengan dikeluarkannya UU No. 22 tahun 1999 tentang pemerintah daerah dan UU No. 25 tahun 1999 tentang perimbangan keuangan antar pemerintah pusat dan daerah, yang sekarang telah diperbarui dengan UU No. 32 tahun 2004 tentang pemerintah daerah dan UU No. 33 tahun 2004 tentang perimbangan keuangan antar pemerintah pusat dan daerah. Bastian (2006: 338) menyatakan bahwa otonomi daerah adalah kewenangan daerah otonom untuk mengatur dan mengurus kepentingan masyarakat setempat menurut prakarsa sendiri berdasarkan aspirasi masyarakat sesuai dengan peraturan perundang-undangan.

Tujuan dari otonomi daerah adalah untuk menciptakan kehidupan politik yang lebih demokratis, menciptakan sistem yang lebih menjamin pemerataan dan keadilan, memungkinkan setiap daerah menggali potensi natural dan kultural yang dimiliki, dan kesiapan menghadapi tantangan globalisasi, serta yang sangat penting adalah terpeliharanya Negara Kesatuan Republik Indonesia. Dengan kata lain, pemerintah ingin melaksanakan pasal 18 UUD 1945, yaitu dengan melaksanakan otonomi yang luas, nyata, dan bertanggungjawab. Menurut Mardiasmo (2002: 24) Desentralisasi tidak hanya berarti pelimpahan wewenang dari pemerintah pusat ke pemerintah yang lebih rendah, tetapi juga pelimpahan beberapa wewenang pemerintahan ke pihak swasta dalam bentuk privatisasi.

Pemberian otonomi daerah berpengaruh terhadap pertumbuhan ekonomi suatu daerah karena memberikan kebebasan kepada pemerintah daerah untuk mengelola dan merencanakan anggaran keuangannya sendiri serta membuat kebijakan-kebijakan yang dapat berpengaruh terhadap kemajuan daerahnya. Hal ini dapat memberikan harapan baru terhadap tumbuhnya pembangunan didaerah secara optimal, tidak lagi terkonsentrasi di pusat. Otonomi daerah membuka kesempatan yang seluas-luasnya bagi daerah untuk mengaktualisasikan segala potensi terbaiknya secara optimal.Dengan begitu, setiap daerah niscaya memiliki satu atau beberapa keunggulan tertentu relatif terhadap daerah lainnya (Bastian, 2006: 356).

Prinsip otonomi daerah memberikan kewenangan yang lebih besar pada daerah untuk mengurus daerahnya. Ini adalah kondisi yang bertolak belakang jika dibandingkan dengan masa-masa sebelumnya.Saat itu, peranan pusat begitu dominan dalam pengelolaan daerah. Daerah tidak diberi kewenangan yang memadai untuk mengembangkan dan memajukan potensi yang sesuai dengan kemampuan dan kehendak masyarakat lokal dan seluruh stakeholder daerah. Dominasi pemerintah pusat ketika itu berwujud dalam berbagai pendekatan pembangunan daerah yang sentralistik sehingga mematikan inisiatif dan kreatifitas daerah. Kebijakan daerah lebih banyak ditentukan pemerintah pusat (Yuwono et al., 2005: 51).

Pemberian otonomi kepada pemerintah daerah diharapkan dapat mempercepat terwujudnya kesejahteraan masyarakat daerah melalui peningkatan pelayanan, pemberdayaan dan peran serta masyarakat dalam membangun daerahnya masing-masing. Dalam rangka penyelenggaraan pemerintahan berdasarkan asas desentralisasi, pemerintah pusat memberikan kewenangan kepada pemerintah daerah untuk memungut pajak atau retribusi dan mengelola Sumber Daya Alam (SDA). Sumber dana bagi daerah terdiri dari Pendapatan Asli Daerah (PAD), Dana Perimbangan (Dana Alokasi Umum), Dana Alokasi Khusus (DAK), dan Dana Bagi Hasil (dana bagi hasilpajak/bagi hasil bukan pajak).

Masalah timbul seiring dengan adanya kebijakan otonomi daerah. Yaitu adanya kesenjangan fiskal antar daerah yang memaksa pemerintah pusat untuk memberikan bantuan berupa dana perimbangan kepada pemerintah daerah. Pemerintah daerah mempunyai kewenangan penuh untuk menggunakan dana perimbangan tersebut. Akan tetapi, kewenangan tersebut memiliki konsekuensi bahwa daerah harus mampu menggunakan dana perimbangan secara efektif dan efisien untuk peningkatan pelayanan publik.

\section{METODE PENELITIAN}

Data yang telah dikumpul selanjutnya disusun secara sistematis sesuai dengan kebutuhan analisis untuk menguji hipotesis yang telah dibuat sebelumnya dengan menggunakan uji regresi linier berganda, dimana sebuah variabel terikat (Y) dihubungkan dengan dua atau lebih variabel (X). 
Analisis Regresi Linier Berganda digunakan untuk mengetahui hubungan antara dua atau lebih variabel independent $(\mathrm{X} 1, \mathrm{X} 2, \ldots . \mathrm{Xn})$ terhadap variabel dependen $(\mathrm{Y})$ secara serentak. Koefisien ini menunjukkan seberapa besar hubungan yang terjadi antara variabel independen $(\mathrm{X} 1, \mathrm{X} 2, \ldots . \mathrm{Xn})$ secara serentak terhadap variabel (Y). Nilai R berkisar antara 0 sampai 1 , nilai semakin mendekati 1 berarti hubungan yang terjadi semakin kuat, sebaliknya nilai semakin mendekati 0 maka hubungan yang terjadi semakin lemah. berikut:

Menurut Sugiyono (2007) pedoman untuk memberikan interpretasi koefisien korelasi sebagai

$0,00-0,199=$ sangat rendah

$0,20-0,399=$ rendah

$0,40-0,599=$ sedang

$0,60-0,799=$ kuat

$0,80-1,000=$ sangat kuat

Adapun model persamaan struktur yang dapat dibentuk adalah sebagai berikut :

$\mathrm{Y} 1=\mathrm{f}(\mathrm{X} 1, \mathrm{X} 2, \mathrm{X} 3, \mathrm{X} 4)$

Keterangan:

$\mathrm{Y}=$ Belanja Pembangunan

$\mathrm{X} 1=$ Pendapatan Asli Daerah

$\mathrm{X} 2=$ Dana Alokasi Umum

$\mathrm{X} 3=$ Dana Bagi Hasil Pajak/Bagi Hasil Bukan Pajak

$\mathrm{X} 4=$ Pertumbuhan Ekonomi

Dari persamaan (3.1) dapat dinyatakan dengan fungsi Cobb Douglas sebagai berikut $Y=\alpha_{0} X_{1}^{\alpha 1} X_{2}^{\alpha 2} X_{3}^{\alpha 3} X_{4}^{\alpha 4}$ atau dalam bentuk persamaan regresii Linear Berganda $\log Y=\operatorname{loga} 0+$ $\mathrm{a} 1 \log \mathrm{X} 1+\mathrm{a} 2 \log \mathrm{X} 2+\mathrm{a} 3 \log \mathrm{X} 3+\mathrm{a} 4 \log \mathrm{X} 4+\mathrm{e} 1$

a1 adalah pengaruh atau elastisitas Pendapatan Asli Daerah terhadap Belanja Pembangunan

$\alpha 2$ adalah pengaruh atau elastisitas Dana Alokasi Umum terhadap Belanja Pembangunan

a3 adalah pengaruh atau elastisitas Dana Bagi Hasil Pajak/Bagi Hasil Bukan Pajak terhadap Belanja Pembangunan

a4 adalah pengaruh atau elastisitas Pertumbuhan Ekonomi terhadap Belanja Pembangunan

e1 adalah suku kesalahan random

Untuk memecahkan permasalahan yang telah dikemukakan pada bab terdahulu dan membuktikan hipotesis maka dilakukan analisis data dengan menggunakan pogram SPSS Versi 17.

\section{Uji Asumsi Klasik}

Uji asumsi klasik ini dilakukan agar memperoleh model regresi yang dapat dipertanggungjawabkan. Uji asumsi klasik dalam penelitian ini menggunakan uji normalitas, heteroskedastisitas, multikolinieritas, dan autokorelasi.

Uji Normalitas

Uji normalitas bertujuan untuk menguji apakah dalam model regresi, variabel dependen dan variabel independen mempunyai distribusi normal atau tidak. Model regresi yang baik adalah yang memiliki distribusi data normal atau mendekati normal. Pengujian normalitas ini dapat dilakukan melalui analisis grafik dan analisis statistik.

\section{1) Analisis Grafik}

Salah satu cara termudah untuk melihat normalitas residual adalah dengan melihat grafik histogram yang membandingkan antara data observasi dengan distribusi yang mendekati normal. Namun demikian, hanya dengan melihat histogram, hal ini dapat membingungkan, khususnya untuk jumlah sampel kecil. Metode lain yang dapat digunakan adalah dengan melihat normal probability plot yang membandingkan distribusi kumulatif dari distribusi normal. Dasar pengambilan keputusan dari analisis normal probability plot adalah sebagai berikut:

Jika data menyebar di sekitar garis diagonal dan mengikuti arah garis diagonal menunjukkan pola distribusi normal, maka model regresi memenuhi asumsi normalitas. 
Jika data menyebar jauh dari garis diagonal dan atau tidak mengikuti arah garis diagonal tidak menunjukkan pola distribusi normal ,maka model regresi tidak memenuhi asumsi normalitas.

2) Analisis Statistik

Mendeteksi normalitas data dapat pula dilakukan melalui analisis statistik yang salah satunya dapat dilihat melalui Kolmogrov - Smirnov test (K-S).

Uji K-S dilakukan dengan membuat hipotesis:

Ho $=$ Data residual terdistribusi normal

$\mathrm{Ha}=$ Data residual tidak terdistribusi normal

Dasar pengambilan keputusan dalam uji K-S adalah sebagai berikut:

Apabila probabilitas nilai Z uji K-S signifikan secara statistik maka H0 ditolak, yang berarti data terdistribusi tidak normal.

Apabila probabilitas nilai $\mathrm{Z}$ uji K-S tidak signifikan statistik maka $\mathrm{H} 0$ diterima, yang berarti data terdistribusi normal.

\section{Uji Heteroskedastisitas}

Uji Heteroskedastisitas bertujuan untuk menguji apakah dalam model regresi terjadi ketidaksamaan variance dari residual satu pengamatan ke pengamatan lain.

Model regresi yang baik adalah yang terjadi homokedastisitas atau tidak terjadi heteroskedastisitas. Untuk mendeteksi adanya heteroskedastisitas dilakukan dengan melihat Grafik Scatterplot antara nilai prediksi variabel dependen yaitu ZPRED dengan residualnya SRESID, dimana sumbu Y adalah Y yang telah diprediksi dan sumbu X adalah residual (Y prediksi dan Y sesungguhnya). Dasar analisis ada atau tidaknya heteroskedastisitas dapat dilakukan sebagai berikut:

Jika ada pola tertentu, seperti titik-titik yang ada membentuk pola tertentu yang teratur, maka diindentifikasikan telah terjadi heteroskedastisitas.

Jika tidak ada pola jelas, serta titik-titik menyebar di atas dan di bawah angka 0 pada sumbu $Y$, maka tidak terjadi heteroskedastisitas.

Analisis menggunakan plot mempunyai kelemahan yang cukup signifikan. Oleh karena itu perlu dilakukan uji statistik yang dapat digunakan untuk mendeteksi ada tidaknya heteroskedastisitas yaitu salah satunya dengan uji glejser. Glejser mengusulkan untuk meregres nilai absolut residual terhadap variabel independen. Jika salah satu variabel independen signifikan secara statistik mempengaruhi variabel dependen, maka ada indikasi terjadi heteroskedatisitas.

\section{Uji Multikolinieritas}

Uji ini bertujuan untuk menguji apakah pada model regresi ditemukan adanya korelasi antar variabel independen. Pada model regresi yang baik seharusnya antar variabel independen tidak terjadi korelasi.

Untuk mendeteksi ada tidaknya multikoliniearitas dalam model regresi dapat dilihat dari tolerance value atau variance inflation factor (VIF). Kedua ukuran ini menunjukkan setiap variabel independen manakah yang dijelaskan oleh variabel independen lainnya.

Tolerance mengukur variabilitas variabel independen yang terpilih yang tidak dijelaskan oleh variabel independen lainnya. Jadi nilai tolerance yang rendah sama dengan niali VIF yang tinggi. Nilai cutoff yang umum dipakai adalah:

Jika nilai tolerance $>10$ persen dan nilai VIF $<10$, maka dapat disimpulkan bahwa tidak ada multikolinearitas antar variabel independent dalam model regresi.

Jika nilai tolerance $<10$ persen dan nilai VIF $>10$, maka dapat disimpulkan bahwa ada multikolonearitas antar variabel independen dalam model regresi.

\section{Uji Autokorelasi}

Uji Autokorelasi bertujuan untuk menguji apakah dalam suatu model regresi linear ada korelasi antara kesalahan pengganggu pada periode $\mathrm{t}$ dengan kesalahan periode $\mathrm{t}-1$ (sebelumnya). Jika terjadi korelasi maka dinamakan ada problem autokorelasi. Model regresi yang baik adalah yang bebas autokorelasi. 
Untuk mendeteksi autokorelasi, dapat dilakukan dengan Uji Durbin Watson (DW test) yang hanya digunakan untuk autokorelasi tingkat satu (first order autocorrelation) dan mensyaratkan adanya intercept (konstanta) dalam model regresi dan tidak ada variabel lagi diantara variabel independent. Hipotesis yang akan diuji adalah:

$\mathrm{H} 0$ : tidak ada autokorelasi $(\mathrm{r}=0)$

HA: ada autokorelasi $(r \neq 0)$

\section{Pengujian Hipotesis}

Pengujian terhadap hipotesis-hipotesis yang diajukan, perlu digunakan analisis regresi melalui uji $\mathrm{t}$ maupun uji $\mathrm{F}$. Tujuan digunakan analisis regresi adalah untuk mengetahui pengaruh variabel-variabel independen terhadap variabel dependen, baik secara parsial maupun simultan, serta mengetahui besarnya dominasi variabel-variabel independen terhadap variabel dependen.

Metode pengujian terhadap hipotesis yang diajukan dilakukan dengan pengujian secara parsial dan pengujian secara simultan. Langkah-langkah untuk menguji hipotesis yang diajukan dalam penelitian ini adalah sebagai berikut:

\section{1) Uji-F}

Tabel F dilakukan untuk mengetahui pengaruh variabel bebas secara bersama-sama terhadap variabel terikat.

Langkah-langkah/ urutan menguji hipotesis dengan distribusi F

Merumuskan hipotesis

Ho : $\beta 1=\beta 2=\beta 3=\beta 4=0$, berarti secara bersama-sama tidak ada pengaruh variabel bebas terhadap variabel terikat.

Ha : $\beta 1 \neq \beta 2 \neq \beta 3 \neq \beta 4 \neq 0$, berarti secara bersama-sama ada pengaruh variabel bebas terhadap variabel terikat.

Menentukan taraf nyata/ level of significance $=\alpha$

Taraf nyata / derajat keyakinan yang digunakan sebesar $\alpha=1 \%, 5 \%, 10 \%$. Derajat bebas (df) dalam distribusi $\mathrm{F}$ ada dua, yaitu :

$\mathrm{df}$ numerator $=\mathrm{dfn}=\mathrm{df} 1=\mathrm{k}-1$

df denumerator $=\mathrm{dfd}=\mathrm{df} 2=\mathrm{n}-\mathrm{k}$

Dimana:

df $=$ degree of freedom/ derajat kebebasan

$\mathrm{n}=$ Jumlah sampel

$\mathrm{k}=$ banyaknya koefisien regresi

Menentukan daerah keputusan, yaitu daerah dimana hipotesis nol diterima atau tidak.

Ho diterima apabila $\mathrm{F}$ hitung $\leq \mathrm{F}$ tabel, artinya semua variabel bebas secara bersama-sama bukan merupakan variabel penjelas yang signifikan terhadap variabel terikat.

Ho ditolak apabila F hitung > F tabel, artinya semua variabel bebas secara bersama-sama merupakan penjelas yang signifikan terhadap variabel terikat.

\section{2) Uji-T}

Uji t pada dasarnya menunjukkan seberapa jauh pengaruh satu variabel bebas secara individual dalam menerangkan variasi variabel terikat. Tujuan dari uji t adalah untuk menguji koefisien regresi secara individual.

Ho adalah satu pernyataan mengenai nilai parameter populasi. Ho merupakan hipotesis statistik yang akan diuji hipotesis nihil.

Langkah-langkah/ urutan menguji hipotesis dengan distribusi t

Merumuskan hipotesis terikat

Ho : $\beta \mathrm{i}=0$, artinya variabel bebas bukan merupakan penjelas yang signifikan terhadap variabel

$\mathrm{Ha}: \beta \mathrm{i} \neq 0$, artinya variabel bebas merupakan penjelas yang signifikan terhadap variabel terikat.

Menentukan taraf nyata/ level of significance $=\alpha$ Taraf nyata $/$ derajad keyakinan yang digunakan sebesar $\alpha=1 \%, 5 \%, 10 \%$, dengan: 
$\mathrm{df}=\mathrm{n}-\mathrm{k}$

Dimana:

df $=$ degree of freedom/ derajat kebebasan

$\mathrm{n}=$ Jumlah sampel

$\mathrm{k}=$ banyaknya koefisien regresi + konstanta

Menentukan daerah keputusan, yaitu daerah dimana hipotesis nol diterima atau tidak. Untuk mengetahui kebenaran hipotesis digunakan kriteria sebagai berikut.

Ho diterima apabila $-\mathrm{t}(\alpha / 2 ; \mathrm{n}-\mathrm{k}) \leq \mathrm{t}$ hitung $\leq \mathrm{t}(\alpha / 2 ; \mathrm{n}-\mathrm{k})$, artinya tidak ada pengaruh antara variabel bebas terhadap variabel terikat.

Ho ditolak apabila thitung $>\mathrm{t}(\alpha / 2 ; \mathrm{n}-\mathrm{k})$ atau $-\mathrm{t}$ hitung $<-\mathrm{t}(\alpha / 2 ; \mathrm{n}-\mathrm{k})$, artinya ada pengaruh antara variabel bebas terhadap variabel terikat.

\section{SIMPULAN}

Berdasarkan analisis dan pembahasan yang telah diuraikan pada bab terdahulu, maka peneliti menarik beberapa kesimpulan sebagai berikut:

1. Pendapatan Asli Daerah berpengaruh positif dan signifikan terhadap Belanja Pembangunan di Provinsi Kalimantan Timur.

2. Dana Alokasi Umum memberikan pengaruh positif tapi tidak memberikan pengaruh yang signifikan terhadap Belanja Pembangunan di Provinsi Kalimantan Timur.

3. Dana Bagi Hasil Pajak/Bagi Hasil Bukan Pajak memberikan pengaruh positif tapi tidak memberikan pengaruh yang signifikan terhadap Belanja Pembangunan di Provinsi Kalimantan Timur.

4. Pertumbuhan Ekonomi memberikan pengaruh negatif dan tidak memberikan pengaruh yang signifikan terhadap Belanja Pembangunan di Provinsi Kalimantan Timur.

5. Dari keempat variabel bebas tersebut hanya variabel Pendapatan Asli Daerah memiliki pengaruhi yang positif signifikan dan dominan terhadap belanja pembangunan di Provinsi Kalimantan Timur.

\section{DAFTAR PUSTAKA}

Arbie Gugus Wandira, 2013, Pengaruh Pendapatan Asli Daerah (PAD), Dana Alokasi Umum (DAU), Dana Alokasi Khusus (DAK), dan Dana Bagi Hasil (DBH) terhadap Pengalokasian Belanja Modal.(Studi Empiris pada Pemerintah Provinsi se-Indonesia tahun 2012), Akuntasi, Universitas Negeri Semarang.

Arsyad, Lincolin, 2004. Ekonomi Pembangunan. Yogyakarta: STIE YKPN.

Badan Pusat Statistik (BPS). Provinsi Kalimantan Timur Dalam Angka. Tahun 2005 - 2014 Badan Pusat Statistik (BPS).

Boediono. 1989. Ekonomi Mikro. Yogyakarta:BPFE

Djojohadikusumo, Sumitro. 1994. Dasar Teori Ekonomi Pertumbuhan dan Ekonomi Pembangunan . Jakarta:LP3ES.

Darwanto, Yulia Yustikasari, 2007, Pengaruh Pertumbuhan Ekonomi, Pendapatan Asli Daerah dan Dana Alokasi Umum terhadap Pengalokasian Anggaran Belanja Modal, Magister Sains Ilmu Ilmu Ekonomi, Management, Akuntasi Universitas Gadjah Mada Jog

Glason, John. 1990. Pengantar Perencanaan Regional. Terjemahan Paul Sitohang. Jakarta: LPEUI.

Gujarati, Damodar N. 1978. Ekonometrika Dasar. Jakarta: Erlangga.

Jhingan, ML. 2003. Ekonomi Pembangunan dan Perencanaan. Jakarta: PT Raja Graindo Persada.

Moleong, Lexi. 2000. Metodologi Penelitian Kualitatif. Bandung: PT Remaja Rosdakarya.

Pemerintah Provinsi Kalimantan Timur : http://kaltimprov.go.id/hal-transparansi-pengelolaananggaran-daerah.htmlhttp://kaltimprov.go.id/hal-transparansi-pengelolaan-anggarandaerah.html 
Riduwan, Engkos Achmad Kuncoro, 2010, Cara Menggunakan dan Memaknai Path Analysis (Analisis Jalur) Bandung Penerbit Alfabeta

Robinson Tarigan. 2005. Ekonomi Regional Teori dan Aplikasi. Jakarta: PT Bumi Aksara.

Sadono Soekirno. 1985. Ekonomi Pembangunan. Jakarta: Lembaga Penerbit Fakultas Ekonomi UI dengan Bima Grafika

Sadono Soekirno. 2011. Pengantar Teori Mikro Ekonomi. Jakarta: PT Raja Grafindo Persada

Suherman Rosyidi, Pengantar Teori Ekonomi (Pendekatan kepada Teori Ekonoi Mikro dan Makro), 2012, Jakarta: PT Raja Grafindo Persada

Surya Hamdani, 2014, Pengaruh Dana Alokasi Umum (DAU) dan Pendapatan Daerah (PAD) terhadap Belanja Daerah pada Kabupaten/Kota di Provinsi Kalimantan Timur, Fakultas Ekonomi Universitas Mulawarman. 